\title{
ANALISIS KOREOGRAFI \\ TARI KETIMANG BURONG SUKU SAWANG
}

\author{
Oleh: \\ Martha Sarassati Afnal \\ Email: saras08@yahoo.com
}

Tari Ketimang Burong adalah sebuah pertunjukan tari yang lahir dari masyarakat suku Sawang Belitung. Tari ini adalah tari kelompok yang ditarikan oleh 6 orang penari laki-laki dan 6 orang penari perempuan secara berpasangan. Dilihat dari gerak, pola lantai, dan syair yang dilantunkan oleh para penyanyi memberikan gambaran mengenai kehidupan keseharian masyarakat suku Sawang yang dahulunya adalah suku yang menghabiskan hidupnya di lautan lepas.

Pemahaman analisis koreografi terdiri dari prinsip-prinsip kebentukan yang meliputi: keutuhan, variasi, repetisi, transisi, rangkaian, perbandingan dan klimaks.Dengan pendekatan Koreografi yang meliputi aspek bentuk, teknik, dan isi, serta menganalisis gerak tari dari aspek tenaga, ruang, dan waktu. Ketiga konsep tersebut merupakan satu kesatuan dalam bentuk tari yang tidak dipisahkan dan merupakan satu kesatuan bentuk tari yang utuh.

Tari Ketimang Burong suku Sawang merupakan suatu tari hiburan dengan bentuk koreografi tari kelompok. Koreografi dalam tari ini memiliki motif gerak yang sangat sederhana, setiap motif geraknya dilakukan berulang-ulang. Dari kesederhanan yang terdapat dalam tari Ketimang Burong menyimpan berbagai makna disetiap hal yang terkait dengan tari tersebut, diantaranya tema, gerak, kostum, pola lantai, dan syair yang menjadi aspek penting dalam tari Ketimang Burong.

Kata kunci: Analisis koreografi, Ketimang Burong, suku Sawang 


\section{ABSTRACT \\ ANALYSIS OF CHOREOGRAPHY KETIMANG BURONG'S DANCE OF SAWANG PEOPLE}

\section{Martha Sarassati Afnal}

This researchment analyze choreography of Ketimang Burong as a dance that comes from Sawang's People of Belitung. This dance is a group dance that was danced by 6 male dancers and 6 female dancers in pairs. This dance is a dance that's very closely related to daily life of the Sawang's people. Judging from the motion, pattern of the floor, and the lyrics that sung by the singer provide an overview of the tribe of Sawang people who were former as the tribe who spend their life in the sea.

This Researchment uses choreography appoarch, covering the aspect of form, technique, and content. And analyze the motion of dance from the aspect of energy, space, and time. The three concepts are unity in the form of dance that is not separated and is a unified whole dance form. The understanding of choreographic analysis consists of the principles of deformity which include : wholeness, variety, repetition, transition, sequence, comparison and climax.

Ketimang Burong dance of Sawang's people is a entertainment dance where the form of choreography is a group dance. Choreography in this dance has a very simply motif, it is like every single of motion motif is done repeatedly. From the simplicity of Ketimang Burong dance, there are various meaning in ever thing related to the dance among theme are theme, motion, costume, floor pattern, and poem which become important aspect in Ketimang Burong dance.

Keyword : Choreography analysis, Ketimang Burong, Sawang's Tribe. 


\section{PENDAHULUAN}

Suku sawang adalah salah satu suku yang terdapat di pulau Bangka dan pulau Belitung. Sawang artinya laut, dan suku Sawang adalah suku laut. Seperti namanya, suku Sawang dahulunya tinggal dan hidup di laut. Mereka menghabiskan hari-hari, di atas sebuah perahu yang biasa mereka sebut dengan Kulek. Perahu inilah sebagai alat untuk matapencaharian di laut sekaligus sebagai perlengkapan hidup mereka.

Muang Jong adalah upacara ritual yang dilakukan oleh suku Sawang yang melibatkan dukun, pemuka adat, dan msyarakat di kalangan mereka, tujuannya sebagai bentuk rasa syukur mereka kepada penguasaha laut. Ritual Muang Jong biasanya dilakukan berhari-hari, dan melewati beberapa tahapan kegiatan, dari mulai menentukan hari dan tanggal pelaksanaan, sampai dengan acara puncak yaitu melarungkan Jong ke tengah laut. Jong merupakan sebuah replika perahu orang Sawang yang berisikan sesaji.

Ketimang Burong adalah salah satu tarian hiburan yang ditarikan pada saat ritual Muang Jong. Ketimang Burong tidak memiliki arti khusus namun menurut hasil wawancara ketimang artinya menimang dan burong artinya burung. Pemberian nama Ketimang Burong berkaitan dengan lagu atau syair yang digunakan untuk mengiringinya. Dahulu kala ketika orang Sawang sedang berlayar ke tengah laut mereka melihat burung Bangau yang sedang hinggap di tiang kulek (perahu). Kicauan burung tersebut seakan menghibur mereka yang sedang berlayar di tengah laut. Orang-orang Sawang kemudian ikut melantunkan syair-syair untuk menghilangkan rasa bosan selama berlayar. Ketika mereka sampai di daratan syair yang berupa nyanyian tadi dipraktikkan dengan menari, hingga kemudian terciptalah tari Ketimang Burong. Tari ketimang burong adalah tarian yang sangat berkaitan dengan ritual muang jong, walaupun fungsinya terbatas hanya sebagai hiburan saja.

Walaupun judulnya menyebut kata Burong yang artinya burung, namun di dalam koreografinya tidak ada gerak tari yang terinspirasi dari gerak laku burung seperti tarian pada umumnya. Inspirasi burung tampak pada pola lantai yang mengingatkan pola burung Bangau atau burung Camar yang terbang berkelompok yang membentuk pola berbaris, pola huruf $\mathrm{V}$ terbalik, pola berjajar serta pola tidak beraturan saat terjadi kekacauan seperti berebut mencari makanan berupa serangga yang terbang. Kata burung juga terdapat di syair nyanyian di awal sampai dengan akhir sajian tari, menyebutkan kata Ketimang Burong.

Tarian Ketimang Burong merupakan tari yang diciptakan oleh pak Said Idris yang berfungsi sebagai sarana sosialisasi dengan 
sesama suku Sawang maupun dengan masyarakat lainnya. Said Idris atau yang biasa dikenal dengan kek Deris adalah salah satu seniman suku Sawang yang juga sekaligus ketua sanggar Ketimang Burong yang tinggal di Kampung laut Belitong. Selain sebagai ketua sanggar Ketimang Burong, beliau juga bertanggung jawab dalam bidang tari dan musik.

Ketimang Burong adalah bentuk tarian yang dimainkan oleh muda-mudi dengan gerakan-gerakan seperti orang mengayuh sampan yang gerakannya mengikuti syair yang dilantunkan oleh penyair. Gerakan tarian Ketimang Burong ini mencerminkan bahwa dahulunya kehidupan suku Sawang berada di perahu dan melaut untuk mencari ikan sebagai makanan pokok mereka. Selain itu juga tarian yang dilakukan oleh laki-laki dan perempuan ini memiliki suatu misi membaurkan antar anggota suku Sawang dengan masyarakat Belitung lainnya atau sebagai sarana mempererat silaturahim.

Ciri khas dari tarian ini terdapat pada gerak kaki dan ayunan tangan. Struktur penyajian dalam tari Ketimang Burong sebagian besar masih berpatok pada Melayu Belitung yang dapat dilihat dari gerak dan busana yang digunakan oleh penari. Secara keseluruhan bentuk koreografi tari Ketimang Burong memiliki daya tarik tersendiri yang justru hadir dari kesederhanaan tarian ini. Di balik kesederhanaan itu tampak pola lantai yang cukup rumit. Terlihat pada saat penari membentuk pola lantai melingkar, di mana penari harus berpindah-pindah tempat secara cepat dan tepat, karena apabila penari tidak fokus maka ia tidak akan kembali ke posisi dan ke pasangan awal masing-masing.

Tari Ketimang Burong termasuk dalam tari hiburan yang menggambarkan kegembiraan muda-mudi suku Sawang. Tarian yang dimainkan pada saat ritual Muang Jong ini merupakan tarian berpasangan yang ditarikan kelompok oleh 12 penari yang terdiri dari 6 penari laki-laki dan 6 perempuan. Dari sekian banyak tarian adat suku Sawang, tari Ketimang Burong mempunyai keistimewaan tersendiri, apabila dilihat dari pola lantai, gerak, maupun syair yang dilantunkan. Gerak dan pola lantai yang dimainkan oleh para penari sebagian besar melambangkan kehidupan orang Sawang yang hidup dan tinggal di laut.

Untuk mengupas permasalahan di atas penulis menggunakan pendekatan koreografi. Peneliti berkonsentrasi untuk menganalisis aspek-aspek koreografi yang meliputi aspek bentuk, teknik, dan isi. Serta menganalisis gerak tari dari aspek tenaga, ruang, dan waktu. Pemahaman analisis koreografi terdiri dari prinsip-prinsip kebentukan yang 
meliputi: keutuhan, variasi, repetisi, transisi, rangkaian, perbandingan dan klimaks. ${ }^{1}$ Selain itu dalam penelitian ini juga menjelaskan tentang kajian teks adalah suatu penelitian tari dilihat dari struktur yang tampak atau secara surface structure meliputi koreografi, dan simbolik. Dalam pendekatan simbolik penelitian ini juga melihat konteks untuk membaca makna yang bisa ditafsirkan secara bebas, namun tetap berpegang kepada suku Sawang sebagai penyangga budaya.

\section{PEMBAHASAN}

Analisis koreografi dalam sebuah istilah terdiri dari dua kata yaitu analisis dan koreografi. Analisis adalah sebuah cara mendeskripsikan atau mencatat sebuah fenomena untuk mengetahui keadaan yang sebenarnya dari sebuah tari yang tampak dari sisi bentuknya. ${ }^{2}$ Dalam koreografi terdapat sebuah kesatuan yang tidak dapat dipisahkan yaitu, gerak, ruang, dan waktu. Selain itu sebuah koreografi akan menjadi lebih hidup apabila terdapat aspek-aspek pendukung lainnya seperti tema, rias dan busana, iringan, pola lantai, dan tempat pertunjukan. Dengan demikian dalam menganalisis tari Ketimang Burong akan mengurai bagian perbagian dari aspek-aspek tarinya. Hal ini dapat dilakukan

${ }^{1}$ Y. Sumandijo Hadi. 2014, Koreografi: Bentuk-Teknik-Isi, Yogyakarta: Cipta Media, p.41.

${ }^{2}$ Y. Sumandiyo Hadi, 2017, Kajian Tari Teks dan Konteks, Yogyakarta: Pustaka, p.23. dengan cara menganalisis konsep isi, bentuk, dan teknik. ${ }^{3}$ Beberapa aspek dalam sebuah pertunjukan meliputi tema, gerak, penari, iringan, tata rias busana, pola lantai, dan tempat pementasan. Adapun penjabarannya sebagai berikut:

A. Tema

Tema utama dalam tari Ketimang Burong adalah kegembiraan dan pertemuan antara muda-mudi suku Sawang. Secara struktur, tari ini terdiri dari 4 bagian berdasarkan adegan yang memiliki tema yang berbeda. Pada bagian introduksi ide atau gagasan yang tampak adalah pertemuan. Mereka bertemu antara satu dengan yang lainnya. Pada bagian ini terlihat pada motif gerak yang dilakukan oleh penari yang masih menggunakan motif lenggang bedayong.

Untuk adegan I gagasan yang terlihat adalah perkenalan. Terlihat pada pola lantai penari yang membentuk lingkaran dan menggunakan motif-motif yang menunjukkan kebersamaan seperti tos besatu. Selain itu pola berpasang-pasangan juga menunjukkan ketertarikan dengan lawan jenis. Dalam adegan II tema yang terdapat adalah permainan. Terlihat pada bagian penari melakukan motif gerak nundok sembunyek penari laki-laki dan perempuan seperti sedang melakukan permainan yang biasa dilakukan

\footnotetext{
${ }^{3}$ Y. Sumandiyo Hadi, 2014, pp.82-83.
} 
oleh anak-anak yaitu permainan "si kancil anak nakal". Untuk adegan III tema yang ditampilkan adalah kedekatan. Hal ini tampak terlihat pada pola lantai penari laki-laki dan perempuan yang melingkar dan saling menyatu serta kegembiraan penari tampak terlihat pada motif gerak betepok-tepok. Terakhir adalah penutup, dalam adegan ini ide atau gagasan yang tampak adalah perpisahan.

\section{B. Penari}

Dalam tari Ketimang Burong yang merupakan salah satu ketegori tari kelompok ditarikan oleh 12 penari. Penari Ketimang Burong terdiri dari 6 penari laki-laki dan 6 penari perempuan. Terdapat pola lantai dan pola gerak yang saling terhubung dan saling mendukung antar penari sehingga membentuk pola berbaris, melingkar, dan selang seling.

Tipe tari Ketimang Burong adalah non literal atau tidak bercerita. Alasan ini berdasarkan pada jenis tari Ketimang Burong yang memang merupakan tarian yang bersifat kerakyakatan. Selain jenis kelamin yang memang terdiri dari laki-laki dan perempuan, pemilihan usia dan postur tubuh tidak begitu penting dalam penyajian tari Ketimang Burong. Seluruh penari memiliki peran yang sama dalam setiap gerak yang dilakukan, karena tari Ketimang Burong merupakan jenis tari pergaulan yang bisa ditarikan oleh siapa saja tanpa melihat dari aspek usia maupun postur tubuh penari.

\section{Koreografi Tari Ketimang Burong}

Koreografi berasal dari bahasa Yunani yang terdiri dari dua kata yaitu choreia dan grapho. Choreia berarti tari massal atau kelompok dan kata grapho yang berarti catatan, sehingga apabila digabungkan berarti proses pencatatan dari sebuah tarian massal. Pemahaman tentang pengertian koreografi kemudian berkembang sehingga seterusnya koreografi dipahami sebagai bentuk garapan tari. ${ }^{4}$ Pemahaman analisis koreografi terdiri dari prinsip-prinsip kebentukan yang meliputi: keutuhan, variasi, repetisi, transisi, rangkaian, perbandingan dan klimaks.

\section{Aspek Bentuk}

Keutuhan tari Ketimang Burong dapat tercipta dengan adanya keterkaitan antar aspek-aspek kebentukannya yang dapat dilihat secara struktural yang terdiri dari beberapa motif gerak antara lain: hormat, jalan begaye, maju bepimpin, nukar-nukar, nundok sembunyek, tos besatu, betepok-tepok, dan terdapat dua motif transisi yaitu lenggang bedayong dan mutar bepimpin. Keutuhan tari Ketimang Burong terlihat dari keutuhan aspek gerak, ruang, dan waktu dari dimulainya tarian sampai akhir pertunjukan.

\footnotetext{
${ }^{4}$ Y. Sumandiyo Hadi, 2014, p.1.
} 
Variasi dalam tari Ketimang Burong masih menggunakan aspek gerak dan ruang. Variasi gerak hanya terdapat dalam variasi ruang yaitu pada gerak tangan. Pada motif gerak lenggang dayong yang merupakan motif dasar pada tarian ini kemudian divariasikan menjadi motif gerak lenggang begaye, maju bepimpin, dan nukar-nukar. Pada semua motif ini gerak kaki dilakukan sama yaitu dengan melangkahkan kaki kanan, ke depan dengan kaki kiri mengikuti pola gerak.

Variasi lain yang terdapat dalam tari Ketimang Burong yaitu pada ruang dan waktu. Ruang yang tercipta oleh gerak meliputi arah dan level. Arah hadap dalam tari Ketimang Burong cenderung ke depan, namun divariasikan dengan arah hadap ke samping, dan ke belakang. Dalam tari Ketimang Burong didominasi dengan level sedang, namun divariasikan dengan level rendah. Hal ini dapat dilihat pada motif gerak nundok sembunyek.

Tari Ketimang Burong dominan memiliki satu pusat perhatian atau focus on one point, akan tetapi dalam motif nundok sembunyek terdapat dua fokus perhatian atau focus on two point. Selain itu dalam pola lantai juga membentuk dua fokus perhatian yaitu pada pola lantai melingkar. Dalam pola lantai ini gerak penari yang membentuk lingkaran kecil yang berada di dalam lingkaran besar berbeda dengan gerak penari yang membentuk lingkaran besar, hal ini mengakibatkan terjadinya dua fokus perhatian atau focus on two point.

Adapun variasi waktu dalam tari Ketimang Burong melibatkan tiga elemen yaitu tempo, ritme, dan durasi. Tempo pada dasarnya tempo datar, karena memang musik yang dimainkan tidak terdapat variasi, hanya terdengar datar dari awal hingga akhir tarian ini dipertunjukkan. Tari Ketimang Burong menggunakan pengulangan yang sama atau ajeg, yaitu pengulangannya berjarak waktu secara teratur. Durasi yang digunakan secara keseluruhan kurang lebih 16.23 detik. Durasi ini dapat lebih panjang atau lebih pendek sesuai dengan syair yang dilantunkan oleh penyanyi.

Sebuah koreografi tampaknya selalu menghendaki adanya prinsip repetisi atau pengulangan. Hal ini yang terdapat dalam hampir semua motif gerak dalam tari Ketimang Burong. Motif-motif gerak tersebut antara lain gerak hormat dilakukan di bagian awal dan bagian akhir. Motif lenggang dayong yang merupakan salah satu transisi dalam tari ini, dilakukan berulang di setiap pergantian bagian dan juga sering dilakukan pada saat pergantian beberapa motif yang lainnya. Motif lenggang begaye dilakukan pada bagian introduksi dan bagian kedua. Motif maju bepimpin dilakukan pada bagian introduksi, 
bagian 1, bagian 2, dan bagian 3. Mutar bepimpin dilakukan pada bagian 1 dan bagian 3. Motif tos besatu dilakukan pada bagian 1 dan bagian 3 .

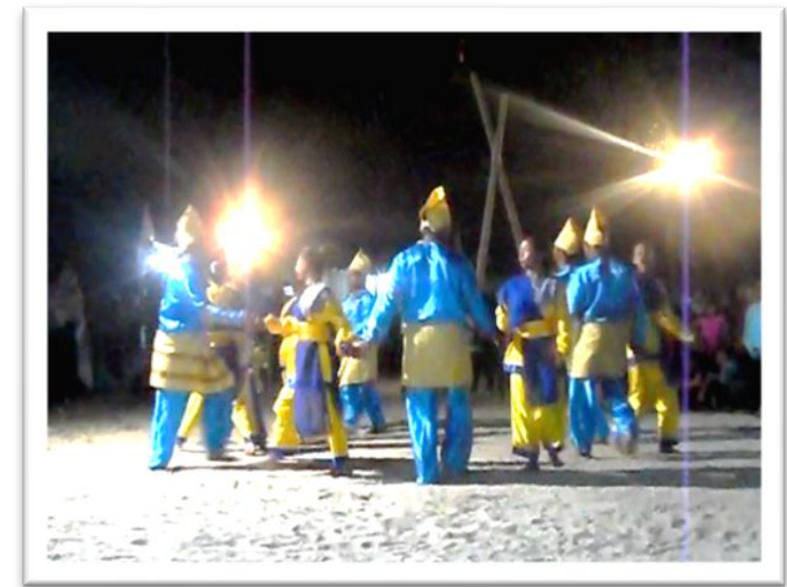

Pengulangan juga terjadi pada masing-masing motif gerak tanpa terkecuali, sehingga satu motif gerak dapat dilakukan pengulangan dua hingga sepuluh kali dalam satu frase gerak. Pengulangan juga terdapat pada lirik lagu, contohnya:

\section{Burong Ketimang Burong \\ Burong pipit memakan la padi \\ Cekai mak cekai cekai timang \\ Gusong are de kali mambang}

Lirik lagu di atas dilakukan berulangulang sebelum isi syair dinyanyikan. Selain pengulangan pada motif dan lirik lagu, pengulangan juga terdapat dalam pola lantai yang dapat dilihat pada setiap transisi per bagian. Pola lantai berbentuk horizontal dan melingkar selalu dilakukan oleh penari pada bagian 1 dan bagian 3 .

Terdapat satu motif transisi yaitu motif mutar bepimpin. Motif gerak ini dijadikan penghubung untuk motif gerak yang satu dengan motif gerak lainnya. Selain terdapat pada motif gerak, transisi juga terdapat pada pola lantai. Pola lantai berbentuk horizontal dijadikan sebagai penghubung antara bagian per bagian. Transisi pola lantai ini terdapat di setiap perpindahan antara bagian satu dengan bagian yang lainnya.

Rangkaian gerak satu dengan gerak yang lainnya dirangkai menjadi satu kesatuan yang utuh, sehingga terciptalah sajian tarian yang menarik untuk dinikmati. Rangkaian tari Ketimang Burong dilakukan terus menerus atau kontinyu. Tari Ketimang Burong bisa dikatakan tidak memiliki klimaks, dikarenakan faktor iringan yang cenderung monoton dan datar dari awal sampai akhir.

\section{Aspek Teknik}

Teknik dipahami sebagai istilah teknik bentuk, teknik medium, dan teknik instrumen. Teknik bentuk dapat dipahami bagaimana membentuk atau mewujudkan sebuah bentuk tari. Teknik medium berupa sebuah gerak dan teknik instrumen yaitu berupa tubuh penari itu sendiri sebagai alat ekspresi. ${ }^{5}$ Teknik bentuk 
dan medium dalam tari Ketimang Burong dapat dilihat dari awal hingga akhir pertunjukan yang mana setiap motif geraknya selalu dilakukan dengan gerak yang rampak dan berulang-ulang. Teknik instrumen terbentuk dari teknik langkah kaki dan ayunan tangan penari. Teknik kaki terbentuk dari bagaimana cara penari menggerakkan kaki secara terus menerus mengikuti alunan musik. Gerak kaki ini adalah melangkah, mengayun, dan juga sebagai penopang tubuh itu sendiri. Hal ini bisa dilihat pada motif-motif lenggang bedayong, lenggang begaye, maju bepimpin, mutar bepimpin, nukar-nukar, tos besatu, nundok sembunyek, dan betepok-tepok. Pada dasarnya tidak terdapat teknik-teknik tertentu dalam melakukan setiap motif gerak. Sebagai kesenian rakyat pada umumnya, para penari hanya belajar pada saat-saat tertentu saja tanpa ada pemahaman mengenai teknik yang benar.

\section{Aspek Isi}

Konteks isi artinya melihat bentuk atau sosok tarian yang tampak secara empirik struktur luar maupun struktur dalamnya. ${ }^{6} \mathrm{Hal}$ ini dapat dipahami bahwa aspek isi adalah inti pokok atau inti permasalahan dalam sebuah tari. Aspek isi sebagai tema cerita dalam sebuah koreografi dikenal dengan istilah literal dan non-literal. Tari Ketimang Burong merupakan salah satu jenis tarian non-literal

\footnotetext{
${ }^{6}$ Y. Sumandiyo Hadi, 2014, p.55
}

karena tidak memiliki cerita, walaupun di balik kisah tarian ini ada sejarah yang melatarbelakanginya. Dalam tari Ketimang Burong terdapat makna tersirat dalam setiap motif maupun pola gerak yang dilakukan oleh penari.

Misalnya pada pola gerak penari membentuk lingkaran sambil berputar, pola gerak ini melambangkan seperti pusaran air di lautan, dan juga seperti pusaran ribuan ikan sarden di lautan. Pada motif gerak nukarnukar penari melakukan gerak selang-seling yang mengibaratkan sebagai pergerakan ikan di bawah laut selain itu juga isi atau makna yang tersirat dalam motif gerak ini adalah pergulatan hidup orang Sawang yang dahulunya hidup di laut.

Setiap pola gerak yang dilakukan penari sebagian besar selalu berkelompok seperti kehidupan ikan di bawah laut. Hal ini menyiratkan bahwa kehidupan orang Sawang selalu berkelompok terutama dalam mencari ikan. Mereka selalu melibatkan sekelompok orang, tujuannya adalah apabila ada musibah yang menimpa salah sau dari mereka, yang lain bisa langsung membantu. Selain itu juga sebagai bentuk silaturahim antar masyarakat suku Sawang. Pada pola lantai 2 baris vertikal, ini melambangkan perahu orang Sawang yang sedang berlayar. Dalam pola lantai horizontal, para penari laki-laki dan perempuan berbaris 
sejajar, maksud yang ingin disampaikan dalam pola gerak ini adalah adanya kesetaraan dan tidak adanya perbedaan dalam meraih tujuan hidup sebagai seorang pelaut yang bisa berbaur dengan siapa saja termasuk dengan orang dengan Melayu.

Motif tari terutama langkah kaki yang berayun ke kanan kiri maupun ke atas dan ke bawah serta gerak tangan seperti mendayung sampan, terinspirasi dari pola kehidupan sehari hari suku Sawang yang dahulunya hidup di lautan. Walau sekarang ini sudah hidup menetap di daratan, namun mata pencaharian mereka tetap sebagai nelayan sehingga laut tetap menjadi pusat dari kehidupan mereka. Gerak mendayung dapat diartikan sebagai kerja keras bertaruh nyawa dalam mencapai kehidupan yang layak. Sedang langkah kaki yang berayun dan bergoyang seperti laju sampan di laut yang terombang ambing ombak menyiratkan bahwa setiap langkah akan menghadapi berbagai aral rintangan yang membutuhkan kepandaian dalam mengatur strategi hidup, harus tetap waspada terhadap gangguan yang kapan saja bisa menerjang tanpa peringatan. Jumlah penari yang banyak dan seimbang antara putra dan putri menyiratkan kesetaraan dalam kebersamaan menghadapi kehidupan, tidak membedakan jenis kelamin, ras, suku, dan agama.
Gerak tari laki-laki dan perempuan ada yang bergandengan atau saling berpegangan tangan, dalam tari Melayu yang berorientasi pada Islam melarang adanya kontak anggota badan secara langsung antara putra dan putri yang bukan muhkrim. Adanya gerakan bergandengan tangan menunjukkan suku Sawang dahulunya animisme, bukan beragama Islam seperti sekarang. Demikian pula pakaian adat yang dikenakan sekarang ini merupakan gaya Melayu yang tidak sesuai dengan latar belakang kehidupan Sawang. Bisa dipetik dari kasus suku Rimba atau Anak Dalam di Jambi, pakaian sehari harinya cawat untuk lelaki, sedang para perempuan hanya mengenakan selembar kain yang dililitkan di badan. Pemerintah Jambi tidak memaksa masyarakat Rimba untuk berpakaian adat seperti masyarakat Melayu. Mestinya pakaian suku Sawang juga bukan seperti suku Melayu, mungkin seadanya, walaupun sederhana pakaiannya namun itulah yang disebut kekayaan budaya yang beraneka ragam, berbeda beda namun tetap satu.

\section{Iringan Tari Ketimang Burong}

Syair dalam tari Ketimang Burong tidak dapat dipisahkan dengan tarinya. Bahkan dapat dikatakan syair memiliki kedudukan yang sama dengan tari, karena dari syairnya dapat 
diketahui cerita apa yang ingin dikisahkan di dalam tari ini. Syair juga menjadi ciri khas masyarakat suku Sawang karena sebagian besar kesenian yang ada pada masyarakat suku Sawang terdapat syair-syair yang bermakna tentang kehidupan suku Sawang. Syair yang dilantunkan pada tarian ini juga dimaksudkan untuk memperkuat suasana.

Selain syair terdapat juga beberapa instrumen yang digunakan di antaranya gimbel, dan tawak-tawak. Gimbel adalah sejenis gendang yang terbuat dari pohon kelapa atau pipa paralon, dengan kulit binatang disalah satu sisinya, biasanya untuk mengiringi tarian digunakan 3-4 buah gimbel yang dimainkan oleh para pemusik. Sedangkan tawak-tawak merupakan alat musik yang terbuat dari perunggu berbentuk seperti gong atau kenong, untuk mengiringi tarian hanya digunakan 1 buah tawak-tawak saja yang berfungsi sebagai penanda ketukan. Gimbel dan tawak-tawak adalah alat musik yang digunakan oleh orang Sawang hampir di setiap kegiatan yang berkaitan dengan kesenian dan ritual. Hal tersebut juga terdapat dalam tari Ketimang Burong yang merupakan salah satu tari adat milik masyarakat suku Sawang.

Salah satu syair dalam tari Ketimang Burong merupakan pantun yang dinyanyikan dari awal tarian sampai dengan berakhir tarian Ketimang Burong, karena pada dasarnya tari
Ketimang Burong merupakan kumpulankumpulan syair yang kemudian ditarikan. Syair nyanyian ini terdiri dari 2 bagian yaitu syair pantun utama dan syair pantun bebas. Syair pantun utama selalu digunakan sebagai pembuka, penutup, dan juga penyeling antar syair pantun bebas. Dengan kata lain syair pantun utama selalu mengapit syair pantun bebas. Syair pantun utama juga harus ada dalam nyanyian pengiring tari Ketimang Burong, dan posisinya tidak boleh digantikan.

\section{E. Tata Rias dan Busana}

Busana yang digunakan penari dalam tari Ketimang Burong menggunakan baju kurung yang merupakan pakaian adat masyarakat Melayu khususnya Melayu Belitung. Selain itu juga mengunakan celana panjang, selendang, dan kain tingkis (setengah betis). Untuk penari laki-laki menggunakan baju panjang dan celana panjang serta menggunakan kain yang diikatkan di bagian pinggang. Bagian kepala mengenakan ikan kepala berupa tanjak. Tata rias terkesan alami dan natural, bahkan hampir tidak menggunakan riasan sama sekali. Para penari perempuan hanya menggunakan bedak tabur yang diusapkan ke muka, sedangkan untuk penari laki-laki hampir tidak menggunakan rias apapun. 
Warna kostum tari Ketimang Burong berwarna biru, sangat jelas menyiratkan warna dunia suku Sawang yaitu lautan yang biru. Sangat dimungkinkan tarian ini tercipta setelah suku Sawang tidak lagi hidup mengelilingi samudra. Bila masih di laut pasti akan menggunakan warna lain atau berwarna warni untuk menghindari kebosanan terhadap warna biru yang menjadi santapan setiap saat suku Sawang. Warna pakaian biru menyiratkan kedamaian dan impian masa lalu tentang lautan.

\section{F. Pola Lantai Tari Ketimang Burong}

Dalam tari Ketimang Burong terdapat dua pola lantai yang dominan yaitu lingkaran dan berbaris 2 lajur ke depan. Pada pola lantai berbaris 2 lajur ke arah depan ini melambangkan perahu orang Sawang yang sedang berlayar. Selain itu terdapat juga pola lantai horizontal, para penari laki-laki dan perempuan berbaris sejajar. Maksud yang akan disampaikan dalam pola gerak ini adalah adanya kesetaraan dan tidak adanya perbedaan dalam meraih tujuan hidup sebagai seorang pelaut yang bisa berbaur dengan siapa saja termasuk orang Melayu.

\section{G. Tempat Pementasan}

Tari Ketimang Burong yang merupakan salah satu bentuk pertunjukan yang membutuhkan tempat pementasan sebagai wadah untuk menuangkan sebuah karya tari. Tempat pementasan tersebut tidak memiliki patokan tertentu, melainkan dapat dipentaskan di mana saja seperti halaman rumah warga, panggung permanen ataupun panggung non permanen. Teknik pementasan dalam tari ini dikemas secara sederhana tanpa ada dekorasi panggung, terutama pada saat pementasan di halaman rumah warga atau di tanah lapang.

\section{PENUTUP}

Tari Ketimang Burong pada awalnya adalah salah satu bentuk kesenian yang menurut penulis adalah kesenian yang tidak memiliki daya tarik dan sisi menarik. Kebudayaan masyarakat suku Sawang yang menjadikan salah satu aset berharga untuk masyarakat Belitung dan masyarakat suku Sawang pada khususnya telah menjadikan tari Ketimang Burong salah satu bagian yang sangat penting dalam penanda atau simbol identitas primordial orang Sawang yang menerangkan bahwa mereka keturunan para pelaut. Tari Ketimang Burong yang pada awalnya hanya sebuah lirik syair yang kemudian dibawakan dengan gerak tarian. Sejalan dengan perkembangan, saat ini tari Ketimang Burong tidak hanya digunakan sebagai tari adat yang fungsinya terbatas, 
namun juga digunakan sebagai sarana hiburan dan tontonan bagi masyarakat.

Tari Ketimang Burong suku Sawang merupakan bentuk koreografi Kelompok berpasangan yang ditarikan oleh 12 penari yang terdiri dari 6 penari laki-laki dan 6 penari peremuan. Ciri khas dari tarian ini terdapat pada gerak kaki dan ayunan tangan. Struktur penyajian dalam tari Ketimang Burong sebagian besar masih berpatok pada Melayu Belitung yang dapat dilihat dari gerak dan busana.

Tari Ketimang Burong suku Sawang menggunakan rias yang sangat sederhana yaitu hanya menggunakan bedak dasar tanpa adanya olesan make up yang digunakan oleh penari. berwarna-warni. Sedangkan kostum yang digunakan memakai celana panjang dan baju kurung Melayu, memakai selendang untuk penari perempuan, dan memakai kain yang diikatkan dipinggang untuk penari laki-laki.

Secara keseluruhan bentuk koreografi tari Ketimang Burong memiliki daya tarik tersendiri yang justru hadir dari kesederhanaan tarian ini. Dari analisis koreografi yang mencakup aspek ruang, gerak tari cenderung kekanan, kiri, belakang dan arah hadap dominan ke tengah. Volume gerakan yang dilakukan tidak pernah lebar, cenderung sempit dan hanya sedikit menggunakan variasi level. Dilihat dari segi waktu gerak tari dilakukan dengan tempo sedang dan banyak pengulangan.

Hasil penelitian ini diharapkan dapat membantu melestarikan kebudayaan suku Sawang khususnya tari Ketimag Burong untuk membantu pengembangan sanggar-sanggar kesenian mengajarkan kesenian berbasis tradisi orang Sawang. Selain itu diharapkan mampu memberikan pemahaman kepada masyarakat Belitung tentang suku Sawang khususnya kesenian yang dimiliki oleh suku tersebut.

\section{DAFTAR SUMBER ACUAN}

\section{A. Sumber Tercetak}

Ellfeld, Louis. 1967. A Primer For Choreographers, University Of Southern California, terjemahan Sal Murgiyanto, 1977. Pedoman Dasar Penata Tari. Jakarta: LPKJ

Hadi, Y. Sumandiyo. 1996. Aspek-aspek Dasar Koreografi Kelompok. Yogyakarta: Manthili. , 2005. Sosiologi Tari. Yogyakarta: Pustaka

2007. Kajian Tari Teks dan Publisher.

2012. Seni Pertunjukan Masyarakat

Penonton. Yogyakarta: BP ISI Yogyakarta.

, 2014. Koreografi (Bentuk-TeknikIsi). Yogyakarta: Cipta Media.

Hawkins, Alma M. 2003. Moving From 
Martha Sarassati Afnal

Within: A New Method for Dance Making (Bergerak menurut Kata Hati).

Terjemahan I wayan Dibia, Jakarta : Ford Foundation dan Masyarakat Seni Pertunjukan Indonesia.

Koentjaraningrat. 1984. Manusia Dan Kebudayaan Di Indonesia. Jakarta Pusat: Djambatan.

\section{B. Narasumber}

Dika, 24 tahun, penari tari Ketimang Burong dari desa Juru Seberang kabupaten Belitung. Idris, 60 tahun, budayawan suku Sawang dari Tanjung Pandan, Kabupaten Belitung.

Lias alias Menan, 60 tahun, budayawan suku Sawang dari desa Juru Seberang kabupaten Belitung.

\section{Diskografi}

Video Tari Ketimang Burong hasil dokumen pribadi peneliti yang di ambil pada saat ritual Muang Jong pada tanggal 11 Februari 2018 di desa Selingsing Gantung. 